\title{
Gorontalo
}

Journal of Government and Political Studies

Volume 3 - NO. 2-Oktober 2020

P-ISSN: 2614-2120 E-ISSN: 2614-2104

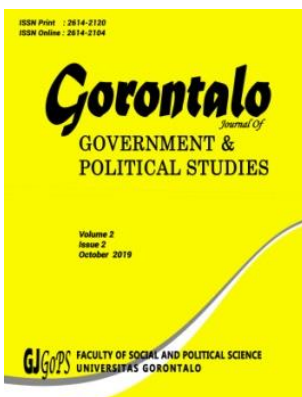

\section{Manajemen Penerapan SP4N LAPOR! Dalam Pelayanan Publik di Kabupaten Bekasi}

\author{
Dhea Desita Delistiana, \\ Hanny Purnamasari, \\ Gun Gun Gumilar \\ Universitas Singaperbangsa Karawang \\ Jl. HS. Ronggo waluyo, Puseurjaya, \\ Kecamatan telukjambe Timur, \\ Kabupaten Karawang, Jawa Barat 41361 \\ 1610631160041@student.unsika.co.id
}

Received: 7th September 2020; Revised: 15th September 2020; Accepted: 17th September 2020

\begin{abstract}
This study intends to analyze problems regarding the management of the National Public Service Complaint Management System for Online Complaints Aspiration Services (SP4N LAPOR!) In Bekasi Regency using management theory proposed by George $R$ Terry in Zaidan Nawawi (2013). The background to the importance of this research is because during the implementation of SP4N in Bekasi Regency no one has researched its management, so that this research is expected to be an evaluation material for the Bekasi Regency Government in managing SP4N LAPOR!. The research method used in this research is qualitative with a descriptive research design. The data collection techniques are carried out through literature study and field studies through observation and interviews. Meanwhile, the data analysis technique is done by using data reduction techniques, data presentation and conclusion drawing. The results of this study explain that the application of SP4N LAPOR! Bekasi District has not been managed optimally if it is seen from the results of the analysis of 4 (four) management functions. The management has not been optimal because the socialization has not been carried out evenly, there are still reports that have not been followed up, there are still agencies that have not operated SP4N LAPOR!, lack of human resources in managing SP4N LAPOR! strict sanctions against agencies that do not follow up on reports and have not operated SP4N LAPOR!.
\end{abstract}

Keywords: management; E-government; SP4N LAPOR!; public service; Bekasi Regency.

\begin{abstract}
ABSTRAK
Penelitian ini bermaksud untuk menganalisis permasalahan-permasalahan mengenai pengelolaan Sistem Pengelolaan Pengaduan Pelayanan Publik Nasional Layanan Aspirasi Pengaduan Online Rakyat (SP4N LAPOR!) di Kabupaten Bekasi dengan menggunakan teori manajemen yang dikemukakan George R Terry dalam Zaidan Nawawi (2013). Yang melatarbelakangi pentingnya penelitian ini dilakukan yaitu karena selama penerapan SP4N di Kabupaten Bekasi belum ada yang meneliti mengenai manajemen pengelolaannya, Sehingga harapan dari dilaksanakannya penelitian ini yaitu dapat menjadi bahan evaluasi Pemerintah Kabupaten Bekasi dalam mengelola SP4N LAPOR!.
\end{abstract}


Peneliti mengkaji permasalahan mengenai manajemen SP4N LAPOR! melalui pendekatan kualitatif dengan desain penelitian deskriptif. Studi pustaka dan studi lapangan melalui observasi dan wawancara merupakan teknik pengumpulan data yang peneliti gunakan. Sedangkan untuk teknik analisis datanya dengan cara mereduksi data, menyajikan data dan penarikan kesimpulan. Hasil analisis dari penelitian ini menjelaskan bahwa penerapan SP4N LAPOR! di Kabupaten Bekasi belum dikelola secara optimal jika dilihat dari hasil analisis 4 (empat) fungsi manajemen. Belum optimalnya pengelolaan tersebut dikarenakan sosialisasi belum dilakukan secara merata, masih terdapat laporan yang belum ditindaklanjuti, masih terdapat instansi yang belum mengoperasikan SP4N LAPOR!, kekurangan sumber daya manusia dalam mengelola SP4N LAPOR!, kurangnya pemahaman para implementor terhadap pengoperasian SP4N LAPOR!, belum adanya sanksi tegas terhadap instansi-instansi yang tidak menindaklanjuti laporan dan belum mengoperasikan SP4N LAPOR!.

Kata Kunci: manajemen; E-government; SP4N LAPOR!; pelayanan publik; Kabupaten Bekasi.

\section{PENDAhUluan}

Pelayanan publik merupakan serangkaian kegiatan yang mana tujuannya untuk memberi kepuasan pelayanan kepada masyarakat. berhasil atau tidaknya pelayanan yang diberikan kepada masyarakat tersebut tergantung pada implementor kebijakan, dalam hal ini adalah pemerintah. Dari waktu ke waktu pelayanan publik terus ditingkatkan oleh pemerintah, salah satunya dengan cara membuat suatu inovasi di bidang elektronik. Pemanfaatan teknologi di bidang pemerintahan tersebut sering kita sebut e-government. E-government pada hakikatnya merupakan suatu inovasi dari pemerintah yang tujuannya mengefektifkan dan mengefisiensikan proses pemberian pelayanan publik. Berdasarkan Instruksi Presiden Republik Indonesia Nomor 3 Tahun 2003 tentang Kebijakan dan Strategi Nasional Pengembangan e-Government bahwa pemerintah harus dapat menjalankan tuntutan masyarakat yang meliputi urusan kepentingan khalayak umum dengan menjunjung tinggi akuntabilitas, dapat dijangkau secara aktif dan mendengarkan aspirasi masyarakat serta memberikan fasilitas sarana komunikasi dalam merumusan suatu kebijakan.

Sejalan dengan hal tersebut maka dikeluarkan pula Peraturan Presiden Nomor 76 Tahun 2013 dan Peraturan Menteri Pendayagunaan Aparatur Negara dan Reformasi Birokrasi Nomor 3 Tahun 2015 sebagai kebijakan yang menetapkan sebuah inovasi pelayanan publik berbasis teknologi yaitu Sistem Pengelolaan Pengaduan Pelayanan Publik Nasional Layanan Aspirasi Pengaduan Online Rakyat (SP4N LAPOR!). SP4N LAPOR! merupakan sarana penampung aspirasi masyarakat yang tujuannya sebagai saluran utama penyampaian aspirasi masyarakat terhadap segala bentuk permasalahan pelayanan publik. Dalam pengimplementasiannya tersebut, SP4N LAPOR! dikelola oleh Kementerian Pendayagunaan Aparatur Negara reformasi Birokrasi (Kemenpan RB), Kantor Staff Presiden (KSP) dan Ombudsman Republik Indonesia (ORI) dan telah dioperasikan oleh kementerian sebanyak 34, lembaga sebanyak 96, serta 493 Pemerintah Daerah.

Kabupaten Bekasi merupakan salah satu daerah yang mengimplementasikan SP4N LAPOR!, terhitung sejak tahun 2013 sampai dengan Februari 2020 sebanyak 921 laporan. Pengimplementasian SP4N LAPOR! di Kabupaten Bekasi tersebut dilatarbelakangi karena belum adanya sarana pengaduan secara efektif kepada pemerintah, mengingat lokasi kantor pemerintah daerah Kabupaten Bekasi jauh dari pemukiman masyarakat, 
sehingga ketika masyarakat ingin melaporkan segala bentuk keluh kesahnya kepada pemerintah harus menempuh jarak yang cukup jauh dan harus mengeluarkan biaya. Maka sebagai respon kepedulian pemerintah Kabupaten Bekasi terhadap permasalahan tersebut, mengimplementasikan SP4N LAPOR! dengan mengacu pada regulasi yang telah ditetapkan sebelumnya. penerapan SP4N LAPOR! tersebut.

Sejak awal pengimplementasiannya, SP4N LAPOR! Kabupaten Bekasi awalnya dikelola oleh Diskominfosantik Kabupaten Bekasi. Namun, SP4N LAPOR! ketika itu kurang mendapatkan respon yang baik, sehingga beberapa tahun ke belakang tidak aktif dikelola. Adapun langkah strategis yang dilakukan oleh pemerintah Kabupaten Bekasi yaitu memindah alihkan pengelolaan SP4N LAPOR! kepada Humas dan Protokol. Hal ini tentunya bertujuan agar SP4N LAPOR! dapat dikelola secara baik sehingga meningkatkan kualitas pelayanan publik di Kabupaten Bekasi.

Namun berdasarkan penelitian, pengelolaan SP4N LAPOR! ini masih belum sempurna, dengan beberapa alasan seperti pertama, sosialisasi belum merata kepada masayarakat, yang tentunya masyarakat banyak belum mengetahui mengenai SP4N LAPOR! dan bagaimana cara mengoperasikannya. Kedua, masih terdapat laporan yang belum ditindaklanjuti. Ketiga, masih terdapat instansi yang belum mengoperasikan SP4N LAPOR!. Keempat, Kekurangan sumber daya manusia yang mengelola sehingga admin harus merangkap jabatan. Kelima, belum adanya sanksi tegas terhadap instansi-instansi yang tidak menindaklanjuti laporan dari masyarakat dan instansi-instansi yang belum mengoperasikan SP4N LAPOR!.

Dari permasalahan-permasalahan tersebut maka perlu diteliti mengenai manajemen penerapan SP4N LAPOR! dalam pelayanan publik di Kabupaten Bekasi dengan menganalisisnya menggunakan teori manajemen yang diutarakan oleh George R Terry dalam Zaidan Nawawi (2013). Pengelolaan SP4N LAPOR! dalam pelayanan publik di Kabupaten Bekasi dapat dikelola secara baik apabila telah memenuhi kriteria 4 (empat) fungsi manajemen tersebut.

Penelitian mengenai SP4N LAPOR! telah dilakukan sebelumnya oleh pertama, Suci Sitoresmi pada tahun 2013 yang bejudul "Efektivitas Sistem Informasi Layanan Aspirasi dan Pengaduan Online Rakyat (LAPOR!) pada Unit Kerja Presiden Bidang Pengawasan dan Pengendalian (UKP4)", hasil dari penelitian tersebut menyatakan bahwa SP4N LAPOR! sudah berjalan dengan Efektif di Unit Kerja Presiden Bidang Pengawasan dan Pengendalian. Kedua, Nataya Anindita pada tahun 2016 dengan judul "Elemen Sukses E-Government: Studi Kasus Layanan Aspirasi dan Pengaduan Online Rakyar (LAPOR!) Kota Bandung", hasil dari penelitian tersebut menyatakan bahwa SP4N LAPOR! memiliki manfaat bagi Kota Bandung, yakni dengan adanya peningkatan substansial respon pemerintah terhadap keluhan masyarakat. Yang menjadi pembeda antara penelitian ini dengan penelitian sebelumnya yaitu pertama, lokus penelitian, yang mana pada penetian ini dilakukan di Kabupeten Bekasi, sedangkan penelitian sebelumnya dilakukan di UKP4 dan Kota Bandung. Kedua, teori yang digunakan, yakni pada penelitian ini menggunakan teori manajemen sedangkan penelitian sebelumnya yang dilakukan oleh Suci Sitoresmi menggunakan teori efektivitas, dan Nataya dengan menggunakan teori elemen sukses e-government. Ketiga, diketahui bahwa hasil penelitian yang dilakukan oleh peneliti menunjukan bahwa pengelolaan SP4N LAPOR! di Kabupaten Bekasi 
sejatinya belum terkelola dengan baik, berbeda dengan penelitian sebelumnya yang menunjukkan bahwa SP4N LAPOR! dapat berjalan secara efektif pada UKP4 dan memberikan manfaat bagi Kota Bandung dalam pelayanan publik.

Penelitian ini bertujuan untuk mendeskripsikan bagaimana pengelolaan SP4N LAPOR! di Kabupaten Bekasi dilihat dari segi perencanaan, pengorganisasian dengan pihak yang terlibat, proses pelaksanaan program, sampai dengan pengawasan. Adapun urgensi dilakukannya penelitian ini karena belum pernah ada yang meneliti mengenai SP4N LAPOR! di Kabupaten Bekasi, sehingga diharapkan hasil dari penelitian ini memberikan manfaat bagi pemerintah Kabupaten Bekasi sebagai bahan masukan dan evaluasi dalam mengelola SP4N LAPOR!.

\section{METODE PENELITIAN}

Peneliti menganalisis segala bentuk permasalahan terkait dengan Manajemen Penerapan SP4N LAPOR! Dalam Pelayanan Publik di Kabupaten Bekasi melalui pendekatan kualitatif dengan desain penelitian deskriptif. Penelitian kualitatif adalah metode-metode untuk mengeksplorasi dan memahami makna yang-oleh sejumlah individu atau kelompok orang-dianggap berasal dari masalah sosial atau kemanusiaan (Creswell. 2016). Peneliti menggunakan pendekatan kualitatif dengan desain penelitian deskriptif karena peneliti menganalisis dan memaparkan sejauh mana Pemerintah Kabupaten Bekasi berhasil mengelola Sistem Pengelolaan Pelayanan Publik Nasional Layanan Aspirasi Pengaduan Online Rakyat (SP4N LAPOR!). Penelitian ini dilaksanakan di Kabupaten Bekasi, Provinsi Jawa Barat khusunya pada perangkat daerah Kabupaten Bekasi.

Segala bentuk permasalahan pengelolaan SP4N LAPOR! di Kabuapten Bekasi akan dianalisis menggunakan teori Manajemen yang dicetuskan oleh George R Terry bahwa terdapat 4 (Empat) Fungsi manajemen yaitu perencanaan (planning), Pengorganisasian (Organizing), Pelaksanaan (Actuating), Pengawasan (Controlling) (Zaidan, 2013). Adapun teknik pengumpulan datanya dilakukan dengan 2 (dua) teknik yaitu:

1) Studi Pustaka

Melalui studi pustaka, peneliti akan memperoleh data dan informasi buku-buku, dokumen-dokumen, jurnal dan literatur lainnya yang berkenaan dengan manajemen penerapan SP4N LAPOR! di Kabupaten Bekasi.

2) Studi Lapangan

Teknik pengumpulan data melalui studi lapangan ini bibagi menjadi 2 (dua) cara yaitu melalui observasi dan wawancara. Peneliti melakukan observasi dengan mengamati segala bentuk kegiatan para pengalola SP4N LAPOR! dan masyarakat Kabupaten Bekasi. Sedangkan untuk Wawancara dilakukan dengan Pranata Humas Ahli Kabupaten Bekasi, Admin SP4N LAPOR! Kabupaten Bekasi, Pejabat Penghubung Kabupaten Bekasi, Dinas Komunikasi Informasi Persandian dan Statistik Kabupaten Bekasi, Masyarakat Kabupaten Bekasi.

Mengenai teknik analisis data, peneliti akan menganalis data tersebut dengan 3 (tiga) teknik, pertama, mereduksi data dengan mengklasifikasikan data yang telah peneliti peroleh menjadi fokus penelitian. Kedua, Penyajian data, yang mana data akan disajikan dalam bentuk deskripsi singkat, tabel, gambar 
dan sejenisnya. Ketiga, Penarikan Kesimpulan dari hasil studi pustaka dan studi lapangan yang peneliti lakukan selama proses penelitian.

\section{HASIL DAN PEMBAHASAN}

Dalam penelitin ini, peneliti akan menganalisis berbagai permasalahan dalam pengelolaan SP4N LAPOR! di Kabupaten Bekasi dengan menggunakan 4 (empat) fungsi manajemen yang mana terdapat keterhubungan antara satu fungsi dengan fungsi lainnya. Teori manajemen tersebut dikemukakan oleh George R. Terry yang dikutip dalam Zaidan Nawawi (2013) dengan penjabaran sebagai berikut:

\subsection{Perencanaan (Planning)}

Ketika pemerintah membuat sebuah kebijakan tentunya harus direncanakan secara matang, mulai dari regulasi yang mengatur, prosedur pelaksanaannya, pola pengawasan dan evaluasi program. Membuat suatu perencanaan tersebut merupakan usaha untuk mencapai suatu tujuan yang telah ditetapkan sebelumnya. SP4N LAPOR! merupakan salah satu platform nasional yang fungsinya sebagai kanal aduan masyarakat terhadap pelaksanaan pelayanan publik. Secara umum, tujuan dari pengimplementasian SP4N LAPOR! yaitu untuk memudahkan masyarakat dalam berkomunikasi dengan pemerintah. Sedangkan tujuan dari pengimplementasian SP4N LAPOR! di Kabupaten Bekasi yaitu agar memudahkan masyarakat ketika ingin menyampaikan segala bentuk pengaduan terkait dengan pelayanan publik kepada pemerintah.

SP4N LAPOR! berfungsi sebagai kanal aduan yang dapat diakses oleh masyarakat melalui website SP4N LAPOR! (www.lapor.go.id), aplikasi SP4N LAPOR! yang dapat diunduh di PlayStore dan AppStore, Twitter, Call Centre, SMS 1708, dan Aplikasi milik daerah yang terintegrasi dengan SP4N LAPOR!. Melalui SP4N LAPOR! tersebut masyarakat dapat menyampaikan aspirasi, kritik, apresiasi, laporan pengaduan dan permintaan informasi kepada pemerintah.

Dalam pengimplementasiannya SP4N LAPOR! di Kabupaten Bekasi mengacu pada beberapa dasar hukum yang termuat dalam Buku Panduan Untuk Penyelenggara dan Administrator Pada Pemerintah Provinsi/Kabupaten Kota Adopsi dan Integrasi LAPOR!-SP4N Untuk Pelayanan Publik yang Lebih Baik Tahun 2016 antara lain:

1. Undang-Undang Nomor 14 Tahun 2008 Tentang Keterbukaan Informasi Publik.

2. Undang-Undang Nomor 37 Tahun 2008 Tentang Ombudsman.

3. Undang-Undang Nomor 25 Tahun 2009 Tentang Pelayanan Publik.

4. Peraturan Pemerintah Nomor 61 Tahun 2010 Tentang Pelaksanaan Undang-Undang Keterbukaan Informasi.

5. Peraturan Pemerintah Nomor 76 Tahun 2012 Tentang Pelaksanaan Undang-Undang Pelayanan Publik.

6. Peraturan Presiden Nomor 76 Tahun 2013 Tentang Pengelolaan Pengaduan Pelayanan Publik Nasional.

7. Peraturan Menteri Pendayagunaan Aparatur Negara danReformasi Birokrasi Nomor 24 Tahun 2014 Tentang Pedoman Pelayanan Publik Secara Nasional. 
8. Peraturan Menteri Pendayagunaan Aparatur Negara dan Reformasi Birokrasi Nomor 3 ahun 2015 Tentang Roadmap Sistem Pengelolaan Pengaduan Pelayanan Publik Nasional.

Selain dasar hukum tersebut, terdapat beberapa dasar hukum lain yang termuat dalam Standar Operasional Prosedur (SOP) LAPOR!-SP4N, antara lain:

1. Memorandum of Understanding (MoU) dan Perjanjian Kerjasama (PKS) antara Kementerian Pendayagunaan Aparatur Negara-Reformasi Birokrasi (KemenPAN-RB), Kantor Staf Kepresindenan (KSP) dan Ombudsman Republik Indonesia (ORI).

2. Surat Edaran Kementerian Pendayagunaan Aparatur NegaraReformasi Birokrasi (KemenPAN-RB) Nomor 4 Tahun 2016.

Namun karena SP4N LAPOR! ini dirasa penting, maka pada tahun 2019, Pemerintah Kabupaten Bekasi mengeluarkan Keputusan Bupati Bekasi Nomor 060/kep.224-org/2019 Tentang Pengelolaan Layanan Aspirasi dan Pengaduan Online Rakyat Sistem Pengelolaan Pengaduan Pelayanan Publik Nasional di Kabupaten Bekasi, hal ini bertujuan sebagai penjabaran lebih lanjut terhadap regulasi tertinggi sebelumnya.

Selain regulasi yang mengatur, tentunya dibutuhkan pula Standar Operasional Prosedur (SOP). SOP yang ada tentunya harus dijalankan sebagaimana mestinya. Adapun SOP pengelolaan SP4N LAPOR! sebagai berikut. Pertama, ketika adanya laporan dari masyarakat melalui SP4N LAPOR!, laporan tersebut harus diverifikasi selama 1-3 hari. Kedua, laporan yang sudah diverifikasi selanjutnya didisposisikan ke pejabat penghubung tiap instansi yang berwenang menangani permasalahan yang dilaporkan untuk memperoleh respon awal dan diteruskan ke bagian yang menanganinya selama 3-5 hari. Apabila permasalahan tersebut bukan kewenangan instansi, maka laporan tersebut akan dikembalikan ke admin. Sedangkan apabila laporan sesuai dengan kewenangan instasi, maka harus ditindaklanjuti selama 5-10 hari. Laporan yang tidak ditindaklanjuti selama 60 hari akan dilaporkan ke Ombudman Republik Indonesia selaku lembaga yang berwenang mengawasi pelaksanaan SP4N LAPOR!.

Akan tetapi, berdasarkan hasil penelitian diketahui bahwa sampai saat ini pihak Humas belum memberikan SOP SP4N LAPOR! secara jelas. Hasil wawancara dengan pejabat penghubung Disdukcapil diketahui bahwa beliau menganggap hal ini menjadi permasalahan dalam pengelolaan laporan, permasalahan tersebut dikarenakan beliau tidak tahu harus mengerjakan laporan-laporan lama atau laporan terbaru. Beliau sendiri mengaku bahwa dirinya merasa bingung karena laporan sudah masuk dari tahun-tahun sebelumnya dan beliau baru ditugaskan diawal tahun 2020, ketika memang SP4N LAPOR! ini telah dikelola sejak lama, seharusnya dapat diketahui siapa pengelola sebelumnya dan bagaimana mekanisme pelaksanaannya. Akan tetapi pada kenyataannya beliau tidak mengetahui siapa pejabat penghubung sebelumnya dan bagaimana prosedur pelaksanaanya. Sehingga beliau merasa keteteran tidak tahu harus mengerjakan laporan mana terlebih dahulu. Adapun laporan yang masuk untuk Disdukcapil sejak pengimplementasian program sampai dengan saat ini berjumlah 267 laporan dan belum ada tindaklanjut.

Selain itu, pejabat penghubung SP4N LAPOR! Kecamatan Cikarang Barat juga mengaku bahwa tidak mengetahui SOP dengan jelas. Selama proses pengelolaannya, ketika ada laporan yang masuk, beliau hanya membaca saja 
laporan dan tidak memberikan respon terhadap laporan tersebut. Seperti laporan mengenai pengaduan bansos corona Aan Suhana yang belum ditindaklanjuti selama 37 hari, laporan pengaduan bansos corona Mamat yang belum ditindaklanjuti selama 33 hari, laporan pengaduan bansos corona Unis Yakub yang belum ditindaklanjuti selama 34 hari, masalah administrasi kependudukan yang belum ditindaklanjuti selama 133 hari, dan laporan mengenai $e$-KTP yang belum ditindaklanjuti selama 137 hari. Sedangkan dalam SOP dijelaskan bahwa seharusnya laporan ditindaklanjuti selama 5-10 hari. Hal tersebut tentunya diluar batas waktu yang telah ditetapkan sebelumnya.

Selain regulasi dan SOP, sosialisasi juga menjadi salah satu faktor yang cukup krusial dalam pemgimplementasian suatu program. Pentingnya sosialisasi tersebut agar program dapat diketahui oleh sasaran kebijakan. Berdasarkan hasil penelitian diketahui bahwa sejak awal pengimplentasianya belum dilaksanakan sosialisasi oleh Diskominfosantik Kabupaten Bekasi. Namun, ketika sudah dialihkan pengelolaanya kepada Humas dan Protokoler, pihak Humas sedang gencar-gencarnya melakukan sosialisasi. Sosialisasi tersebut dilakukan melalui media sosial instagram dan facebook. Selain itu juga melaksanakan sosialisasi langsung yang dilaksanakan di Hotel Ayola pada 24 Oktober 2019 yang dihadiri oleh perwakilan tiap-tiap instansi pemerintahan Kabupaten Bekasi sampai dengan tingkat kecamatan. Akan tetapi sangat disayangkan sosialisasi langsung tersebut tidak dilakukan ke masyarakat, sehingga dampaknya program tersebut tidak tepat sasaran. Karena pada dasarnya sasaran dari program tersebut tidak hanya perangkat daerah saja, tapi masyarakat juga.

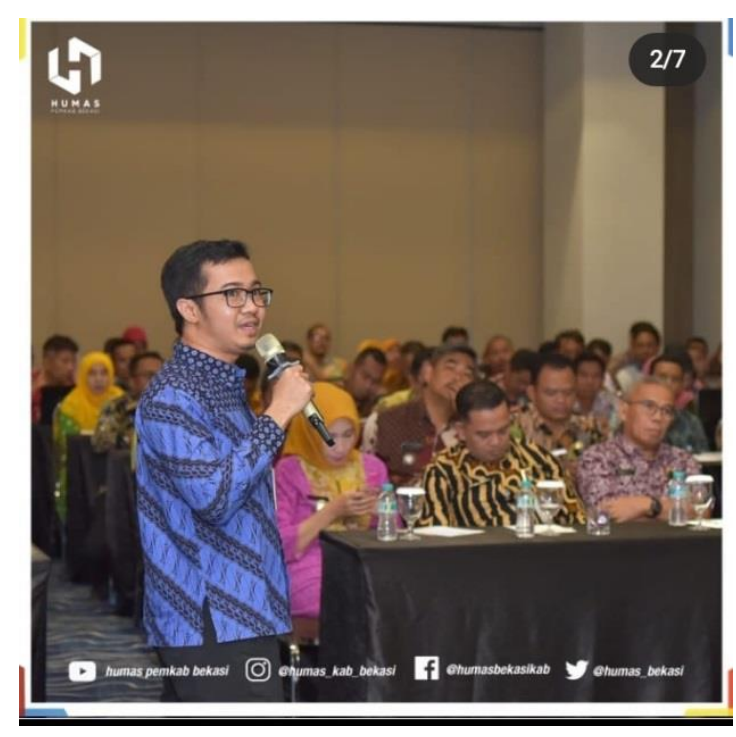

Gambar 1. Sosialisasi SP4N LAPOR! di Hotel Ayola Kabupaten Bekasi

Dari permasalahan-permasalahan tersebut sejatinya perlu pengoptimalan pengelolaan SP4N LAPOR! di Kabupaten Bekasi guna tercapainya suatu tujuan yang telah ditetapkan sebelumnya. 


\subsection{Pengorganisasian (Organizing)}

Dalam menjalankan suatu program, proses koordinasi harus berjalan dengan baik. Pengorganisasian merupakan salah satu faktor penting dalam manajemen. Pengorganisasian juga berarti mengatur segala sesuatu agar dapat berjalan sebagaimana mestinya. dalam pengorganisasian tentunya harus terdapat pembagian kerja, pendelegasian wewenang dan menjalin koordinasi yang baik dengan pihak yang berkaitan dengan program tersebut. Adapun lembaga-lembaga yang bertanggungjawab dalam pengelolaan SP4N LAPOR! ditingkat pusat terdiri dari pertama, Kementerian Pendayagunaan Aparatur Negara reformasi Birokrasi (Kemenpan-RB) yang bertanggungjawab membuat kerangka kebijakan pelaksanaan SP4N LAPOR!, mengadakan sosialisasi, memberikan pembinaan mekanisme pengelolaan SP4N LAPOR!, dan mengelola laporan. Kedua, kantor Staff Presiden (KSP) yang bertanggungjawab mengembangkan sistem aplikasi SP4N LAPOR!, memfasilitasi aplikasi yang terintegrasi dengan SP4N LAPOR!, menyediakan modul SP4N LAPOR!, melaksanakan pengawasan dan pengendalian data laporan. Ketiga, Ombudsman Republik Indonesia (ORI) bertanggungjawab sebagai pengawas dalam pengelolaan SP4N LAPOR!, mengelola laporan yang masuk ke Ombudsman, menindaklanjuti permasalahan dalam pengelolaan SP4N LAPOR!.

Selanjutnya, pengimplementasian SP4N LAPOR! juga dikelola oleh Admin dan Pejabat Penghubung. Fungsi dan wewenang admin dan pejabat pengubung ini tentunya berbeda. Admin merupakan pengelola ditingkat Pusat dan Kabupaten/Kota, untuk di Kabupaten Bekasi sendiri yang menjadi admin SP4N LAPOR! yaitu 2 orang staff Humas dan Protokoler, admin memiliki fungsi dan wewenang mengelola SP4N LAPOR! dilingkungan pengelola, meneruskan laporan dari masayarakat ke pejabat penghubung instansi terkait, melakukan pemantauan terhadap tindaklanjut laporan, dan melakukan evaluasi secara berkala. Sedangkan pejabat penghubung merupakan pengelola ditiap-tiap instasi perangkat daerah dengan fungsi dan wewenang menerima laporan yang didisposisikan oleh admin, memberikan respon awal terhadap laporan yang masuk dan menyampaikan laporan ke bidang terkait.

Penetapan pejabat penghubung ditiap instansi tersebut tentunya sesuai dengan SK Bupati Kabupaten Bekasi, yang mana telah ditetapkan 1 (satu) atau 2 (dua) orang pejabat sesuai dengan kebutuhannya. Namun, berdasarkan hasil penelitian, masih terdapat pejabat penghubung yang belum memahami tugasnya sebagai pejabat penghubung. Seperti yang dijelaskan oleh Pejabat Penghubung Dinas Pekerjaan Umum dan Penataan Ruang bahwa beliau kurang memahami bagaimana pengoperasian SP4N LAPOR!, hal ini dikarenakan PUPR sendiri belum mengoperasikan SP4N LAPOR!. Sehingga hal tersebutlah yang menjadi salah satu penghambat dalam pengelolaan SP4N LAPOR!, sebagaimana dijelaskan pula oleh Pejabat Penghubung Dinas Kesehatan yang menyatakan bahwa dalam mengelola SP4N LAPOR! ini memiliki hambatan seperti apabila laporan yang merupakan bukan wewenang instansi terkait ketika akan dilemparkan ke instansi yang lebih berwenang, laporan tersebut tidak dapat dilemparkan karena masih terdapat instasi yang belum mengoperasikan SP4N LAPOR!, hal ini yang mampu menghambat pola koordinasi. 


\subsection{Pelaksanaan (Actuating)}

Apabila perencanaan dan pengorganisasian suatu program tidak dikelola dengan baik, tentunya akan berpengaruh pada proses pelaksanaannya. Dalam pelaksanaan suatu program, implementor harus memahami tugas dan fungsinya, serta harus berusaha untuk mencapai sasaran agar hasil yang diperoleh dapat membawa manfaat. Pengelolaan SP4N LAPOR! di Kabupaten Bekasi awalnya dikelola oleh Dinas Komunikasi Informatika, namun saat itu kurang mendapatkan repon baik dan sempat tidak aktif beberapa tahun kebelakang. Akhirnya pada tahun 2019, pengelolaan SP4N LAPOR! dipindahkan ke Humas dan Protokoler dengan harapan agar pengelolaannya dapat berjalaan dengan baik. Namun, berdasarkan hasil penelitian terdapat hambatan yaitu mengenai sumber daya manusia yang mengelola, yang mana dalam hal ini admin dan pejabat penghubung masih merangkap jabatan. Bahkan beberapa instansi tidak mengalokasikan sumber daya manusianya untuk mengelola SP4N LAPOR! salah satunya Dinas Lingkungan Hidup, Dinas Pekerjaan Umum dan Penataan Ruang, Kecamatan Cikarang Utara, Kecamatan Cikarang Timur. Hal ini tentunya perlu adanya perhatian khusus agar memaksimalkan penerapan SP4N LAPOR! di Kabupaten Bekasi.

Selanjutnya, Berdasarkan hasil wawancara peneliti dengan beberapa masyarakat Kabupaten Bekasi dapat diketahui bahwa masyarakat lebih tertarik melaporkan permasalahan pelayanan publik secara langsung atau melapor melalui media sosial instagram dan facebook dibanding dengan SP4N LAPOR!. Hal ini dikarenakan instagram dan facebook merupakan media sosial yang telah menjadi tren di kalangan masyarakat. Beberapa pejabat penghubung seperti Kecamatan Cikarang Barat dan Cikarang Utara menyatakan bahwa SP4N LAPOR! kurang diminati, masyarakat lebih banyak melaporkan permasalahan pelayanan publik melalui instagram dan facebook karena mayoritas masyarakat memiliki media sosial tersebut. Selain itu juga dianggap mudah dalam melakukan komunikasi, contohnya ketika ada pengaduan melalui komentar atau pesan di facebook maupun instagram terdapat notifikasi, jadi pengelola langsung memberi tanggapan mengenai laporan tersebut. Sedangkan menurutnya SP4N LAPOR! tidak demikian, mereka pribadi pun sudah jarang membuka aplikasi tersebut.

Terkait dengan seberapa tinggi tingkat presentase laporan melalui instagram dan facebook ini tidak dapat diketahui jumlah pastinya. Pranata Humas Ahli Kabupaten Bekasi menjelaskan bahwa laporan melalui sosial media tersebut tidak dibuatkan laporan mengenai seberapa banyak aduan yang masuk dikarenakan laporan melalui instagram dan facebook biasanya kurang mendetail. Meskipun demikian, pihak pengelola biasanya akan membalas komentar atau pesan yang telah disampaikan oleh masyarakat tersebut sebagai respon awal tindaklanjut laporan.

Sejak awal penerapan SP4N LAPOR! di Kabupaten Bekasi pengelolaanya belum sepenuhnya baik, hal tersebut dibuktikan bahwa masih terdapat laporan yang belum ditindaklanjuti. Adapun jumlah laporan yang masuk dari masyarakat melalui SP4N LAPOR! sebagi berikut : 
Tabe1 1: Data Pengaduan SP4N LAPOR! Kabupaten Bekasi

\begin{tabular}{lcccccccc}
\hline Keterangan & \multicolumn{8}{c}{ Tahun } \\
\cline { 2 - 9 } & $\mathbf{2 0 1 3}$ & $\mathbf{2 0 1 4}$ & $\mathbf{2 0 1 5}$ & $\mathbf{2 0 1 6}$ & $\mathbf{2 0 1 7}$ & $\mathbf{2 0 1 8}$ & $\mathbf{2 0 1 9}$ & $\mathbf{2 0 2 0}$ \\
Belum & 4 & 17 & 29 & 8 & 71 & 144 & 455 & 68 \\
$\begin{array}{l}\text { Ditindak } \\
\text { lanjuti }\end{array}$ & & & & & & & & \\
Proses & & & & & & & 2 & 2 \\
Selesai & & & 3 & 1 & 22 & 16 & 71 & 8 \\
Jumlah & 4 & 17 & 32 & 9 & 93 & 160 & 528 & 78 \\
\hline
\end{tabular}

Sumber: Admin SP4N LAPOR! Republik Indonesia, 2020

Laporan yang masuk pada tahun 2013 sebanyak 4 laporan dan sampai saat ini belum ditindaklanjuti, laporan tersebut mengenai pelayanan publik di Kabupaten Bekasi ini meliputi infrastruktur, keamanan dan ketertiban masyarakat, kesehatan dan perumahan. Di tahun 2014 terdapat 17 laporan masuk dan belum ditindaklajuti, laporan tersebut meliputi permasalan administrasi kependudukan, permasalahan kepolisian, lingkungan hidup dan penanggulangan bencana, pelayanan masyarakat, penyerapan anggaran, pertanahan dan pemukiman, reformasi agrarian, serta reformasi birokrasi dan tata kelola.

Selanjutnya, di tahun 2015 laporan yang masuk sebanyak 32 laporan dengan 29 laporan belum ditindaklanjuti, 3 laporan selesai ditindaklanjuti. Laporan tersebut meliputi permasalahan administrasi kependudukan, dana desa, infrastruktur, keamanan dan ketertiban masyarakat, kepegawaian, koperasi, UKM dan ekonomi kreatif, serta listrik. Di tahun 2016 laporan yang masuk sebanyak 9 laporan dengan 8 laporan belum ditindaklajuti, 1 laporan selesai ditindaklanjuti. Laporan tersebut meliputi permasalahan administrasi kependudukan, kesehatan, lingkungan hidup dan penanggulangan bencana, pelayanan masyarakat dan pendidikan.

Pada tahun 2017 laporan yang masuk sebanyak 93 laporan, dengan 71 laporan belum ditindaklanjti, 22 laporan selesai ditindaklanjuti. laporan tersebut berkenaan dengan permasalahan administrasi kependudukan, dampak lingkungan, hubungan internasional, infrastruktur, keamanan dan ketertiban masyarakat, serta kepegawaian. Untuk tahun 2018 laporan yang masuk sebanyak 160 laporan dengan 144 laporan belum ditindaklanjuti dan 16 laporan selesai, permasalahan yang dilaporkan saat itu meliputi administrasi kependudukan, bisnis dan perdagangan, dampak lingkungan, dana desa, infrastruktur, keamanan dan ketertiban masyarakat.

Sedangkan di tahun 2019 laporan yang masuk sebanyak 528 laporan, 455 laporan belum ditindaklanjuti, 2 laporan dalam proses, 71 laporan selesai ditindaklanjuti. Laporan tersebut meliputi permasalahan administrasi kependudukan, apresiasi, banjir, bantuan langsung sementara masyarakat, bantuan pangan dan bantuan sosial. Terakhir pada Januari-Februari 2020 jumlah klaporan yang masuk sebanyak 78 laporan dengan 68 laporan belum ditindaklanjuti, 2 laporan dalam proses tindaklanjut, 8 laporan selesai ditindaklanjuti. Laporan tersebut mengenai permasalahan administrasi, administrasi kependudukan, administrasi pendaftaran online, bantuan siswa 
miskin, bantuan sosial, dampak lingkungan, infrastruktur, kategori keluhan, keamanan dan ketertiban masyarakat.

Dari penjabaran diatas dapat kita ketahui bahwa penerapan SP4N LAPOR! di Kabupaten Bekasi dari segi pelaksanaannya belum dapat mencapai tujuan yang diharapkan sebelumnya yaitu meningkatkan kualitas pelayanan publik karena dalam pengelolaanya tersebut belum dilakukan secara optimal.

\subsection{Pengawasan (Controlling)}

Pengawasan merupakan salah satu hal yang cukup krusial, dengan adanya pengawasan diharapkan dapat memecahkan permasalahan yang ada, sehingga dapat diketahui cara apa yang harus dilakukan agar mencapai suatu tujuan yang diharapkan. Melalui pengawasan pula implementor dapat melaksanakan suatu tindakan apabila terjadi penyimpangan. Dilihat dari segi pengawasan, Admin tidak memiliki bentuk pengawasan khusus, akan tetapi mereka membuat laporan pertanggungjawaban setiap mingguan, bulanan dan tahunan yang akan diserahkan kepada Sekretariat Daerah dan diteruskan ke Bupati. Namun sejauh ini belum diadakan rapat evaluasi mengenai penerapan SP4N LAPOR!. Pentingnya pengawasan dan evaluasi terhadap pelaksanaan SP4N LAPOR! ini agar dapat mengetahui strategi apa saja yang selanjutnya harus dilakukan apabila terjadi penyimpangan terhadap rencana yang telah ditetapkan sebelumnya.

Selain itu, pemerintah Kabupaten Bekasi tidak memberikan sanksi secara tegas terhadap instansi-instansi yang tidak menindaklanjuti laporan dan instansi-instansi yang belum mengoperasikan SP4N LAPOR!. Pemberian sanksi tersebut guna meminimalisir terjadinya penyimpangan terhadap pelaksanaan SP4N LAPOR! di Kabupaten Bekasi.

\section{PENUTUP}

Berdasarkan hasil analisis peneliti terhadap manajemen penerapan Sistem Pengelolaan Pengaduan Pelayanan Publik Nasipanal Layanan Aspirasi Pengaduan Online Rakyat (SP4N LAPOR!) dalam pelayanan publik di Kabupaten Bekasi dengan memakai teori Manajemen yang dicetuskan oleh George R Terry dapat ditarik kesimpulan bahwasanya penerapan SP4N LAPOR! di Kabupaten Bekasi belum terkelola secara optimal, hal tersebut dikarenakan sosialisasi belum dilakukan secara merata, masih terdapat laporan yang belum ditindaklanjuti, masih terdapat instansi yang belum mengoperasikan SP4N LAPOR!, kekurangan sumber daya manusia dalam mengelola SP4N LAPOR!, kurangnya pemahaman para implementor terhadap pengoperasian SP4N LAPOR!, belum adanya sanksi tegas terhadap instansi-instansi yang tidak menindaklanjuti laporan dan belum mengoperasikan SP4N LAPOR!.

Dari permasalahan yang telah diuraikan tersebut, maka peneliti memberikan rekomendasi kepada pemerintah Kabupaten Bekasi antara lain :

1) Pemerintah Kabupaten Bekasi tidak hanya melakukan sosialisasi melalui media sosial saja, akan tetapi harus mengadakan sosialisasi secara langsung dan merata kepada masyarakat dengan mengumpulkan masyarakat disuatu tempat seperti di kecamatan ketika dilaksanakannya minggon. Kemudian sosialisasi juga dilakukan dengan membuat banner yang dipasang di tempat-tempat strategis yang banyak didatangi oleh 
masyarakat, serta membagikan brosur atau pamflet mengenai SP4N LAPOR!.

2) Menindaklanjuti instansi-instansi yang belum mengoperasikan SP4N LAPOR! dan instansi yang belum menindaklanjuti laporan dengan memberikannya sanksi.

3) Menempatkan sumber daya manusia yang mahir sesuai dengan kemampuanya yaitu dapat mengoperasikan SP4N LAPOR!.

4) Memberikan pembinaan dan pelatihan terhadap pejabat penghubung SP4N LAPOR!.

5) Mengadakan rapat evaluasi minimal dilakukan pertahun.

\section{DAFTAR PUSTAKA}

Birokrasi, K. P. A. N. dan R., Presiden, kantor S., \& Indonesia, O. R. (2016). Buku Panduan Untuk Penyelenggara Dan Administrator Pada Pemerintah Provinsi/Kabupaten/Kota Adopsi Dan Integrasi LAPOR!-SP4N Untuk Pelayanan Publik Yang Lebih Baik.

Creswel, John. (2016). Reseach Desain. Yogyakarta: Pustaka Pelajar.

Instruksi Presiden Republik Indonesia Nomor 3 Tahun 2003 tentang Kebijakan dan Strategi Nasional Pengembangan e-Government. (2003).

KemenPAN-RB. (2016). Surat Edaran Kementerian Pendayagunaan Aparatur Negara-Reformasi Birokrasi (KemenPAN-RB) Nomor 4 Tahun 2016.

Kementerian PANRB. (2018). Standar Operasional Prosedur (Sop) Lapor ! - P4N.

Menteri Pendayagunaan Aparatur Negara dan Indonesia, R. B. R. (2015). Peraturan Menteri Pendayagunaan Aparatur Negara dan Reformasi Birokrasi Republik Indonesia Nomor 3 Tahun 2015 Tentang Road Map Pengembangan Sistem Pengelolaan Pengaduan Pelayanan Publik Naional. In Acta Universitatis Agriculturae et Silviculturae Mendelianae Brunensis (Vol. 16, Issue 2, pp. 39-55). https://doi.org/10.1377/hlthaff.2013.0625

Nataya Anindita. (2002). Elemen Sukses E-Government: Studi Kasus Layanan Aspirasi dan Pengaduan Online Rakyar (LAPOR!) Kota Bandung. Bandung: Universitas Katholik Parahyangan. 1-41. http://documents.worldbank.org/curated/en/2002/11/5732214/egovernment-handbook-developing-countries-e-government-handbookdeveloping-countries-project-infodev-center-democracy-technology

Nawawi, Zaidan. (2013). Manajemen Pemerintahan. Jakarta: PT. RajaGrafindo Persada.

Sitoresmi, S. (2013). Efektivitas Sistem Informasi layanan Aspirasi dan Pengaduan Online Rakyat (LAPOR!) Pada Unit Kerja Presiden Bidang Pengawasan dan Pengendalian Pengendalian Pembangunan (UKP4). Skripsi, 1-137. http:/ / blog.lapor.go.id/images/publikasi/SuciSitoresmi.pdf

SK Bupati Bekasi - SP4N LAPOR.PDF. (2019). 